\title{
Increasing Waterflood Reserves in the Wilmington Oil Field Through Improved Reservoir Characterization and Reservoir Management
}

\author{
Quarterly Report \\ October 1 - December 31, 1997 \\ By: \\ Roy Koerner; Don Clarke \\ Scott Walker; Chris Phillips \\ John Nguyen; Dan Moos; Kwasi Tagbor
}

Work Performed Under Contract No.: DE-FC22-95BC14934

\author{
For \\ U.S. Department of Energy \\ Office of Fossil Energy \\ Federal Energy Technology Center \\ P.O. Box 880 \\ Morgantown, West Virginia 26507-0880
}

By

City of Long Beach

Department of Oil Properties

Long Beach, California 90801 


\section{Disclaimer}

This report was prepared as an account of work sponsored by an agency of the United States Government. Neither the United States Government nor any agency thereof, nor any of their employees, makes any warranty, express or implied, or assumes any legal liability or responsibility for the accuracy, completeness, or usefulness of any information, apparatus, product, or process disclosed, or represents that its use would not infringe privately owned rights. Reference herein to any specific commercial product, process, or service by trade

name, trademark, manufacturer, or otherwise does not necessarily constitute or imply its endorsement, recommendation, or favoring by the United States Government or any agency thereof. The views and opinions of authors expressed herein do not necessarily state or reflect those of the United States Government or any agency thereof. 


\section{"INCREASING WATERFLOOD RESERVES IN THE WILMINGTON OIL FIELD THROUGH IMPROVED RESERVOIR CHARACTERIZATION AND RESERVOIR MANAGEMENT"}

Cooperative Agreement Number DE-FC22-95BC14934

Tidelands Oil Production Company (TOPKO), Long Beach, CA

City of Long Beach, Department of Oil Properties

Stanford University, Stanford, CA

Magnetic Pulse, Inc. (MPI), Houston, TX

Date of Report

Award Date

Anticipated Completion Date

Government Award

Principal Investigators

Program Managers

Reporting Period
January 26, 1998

March 21, 1995

March 20, 2000

$1997 \$ 294,505$

Roy Koerner, City of Long Beach Don Clarke, City of Long Beach Scott Walker, Tidelands Oil Production Co. Chris Phillips, Tidelands Oil Production Co. John Nguyen, Tidelands Oil Production Co. Dan Moos, Stanford University Kwasi Tagbor, MPI

Roy Koerner, City of Long Beach Don Clarke, City of Long Beach Scott Walker, Tidelands Oil Production Co.

October 1, 1997 to December 31, 1997 


\section{Objectives}

The objectives of this quarterly report are to summarize the work conducted under each task during the reporting period October - December 1997 and to report all technical data and findings as specified in the "Federal Assistance Reporting Checklist".

The main objective of this project is the transfer of technologies, methodologies, and findings developed and applied in this project to other operators of Slope and Basin Clastic Reservoirs. This project will study methods to identify sands with high remaining oil saturation and to recomplete existing wells using advanced completion technology.

The identification of the sands with high remaining oil saturation will be accomplished by developing a deterministic three dimensional (3-D) geologic model and by using a state of the art reservoir management computer software. The wells identified by the geologic and reservoir engineering work as having the best potential will be logged with cased-hole logging tools. The application of the logging tools will be optimized in the lab by developing a rock-log model. This rock-log model will allow us to translate measurements through casing into effective porosity and hydrocarbon saturation.

The wells that are shown to have the best oil production potential will be recompleted. The recompletions will be optimized by evaluating short radius lateral recompletions as well as other recompletion techniques such as the sand consolidation through steam injection.

\section{Summary of Technical Progress}

\section{- Reservoir Characterization}

Collection of circumferential strain data from well $169-\mathrm{W}$ core samples is complete and will permit a direct measurement of static Poisson's ratio. The results will provide a test of the Gassmann relations and of the relationship between the ultrasonic (pulse transmission) measurements of moduli and the static moduli. This new information will complete the data set proposed for collection at the start of the project and allow calibration of the acoustic saturation information from well logs. Results are confirming theoretical expectations. 
- Reservoir Engineering

Researchers updated the cross section and bubble maps for the Tar Zone in Fault Block 5. This is the zone in which Budget Period \#1 recompletion $\mathrm{J}-15$ is situated. Researchers are evaluating candidate wells $\mathrm{J}-106$ and $\mathrm{J}-79$ which are completed in a deeper zone but pass through the Tar Zone, Fault Block 5, in the study area.

\section{- Deterministic 3-D Geologic Modeling}

A review of the $\mathrm{J}-17$ Logging While Drilling (LWD) response as it related to our geologic model showed several inconsistencies. Other data suggested our geologic model was accurate and the interpretation problem was due to the LWD algorithm. The interpretation algorithm was deemed too simplistic for the heterogeneity of the formation. Additional log data was gathered from surrounding wells and digitized for a new resistivity model.

The new algorithm makes a number of assumptions, the primary being that all the curve separation is caused by anisotropy (no invasion, eccentricity, thin bed or dielectric effects). If there are additional effects causing curve separation then these would become apparent when comparing the modeled and real data sets. The new modeled resistivities were closer to the wireline resistivities of offset wells $\mathrm{J}-58$ and $\mathrm{J}-121$.

The anisotropic ratios were between 2:1 and 4:1. Higher values would indicate external influences like invasion, a formation effect, relative dip change or a change in the dielectric constant. The Rt horizontal and Rt vertical were forward modeled and compared with the real time data set. They compared well except toward the end of the well. The conclusion was that if the model is correct, the realtime data indicates that the $\mathrm{Hx}_{0}$ is not laterally homogenous. We know this is true because a facies change can be seen in the cross sections and logs.

An anomaly at $1061 \mathrm{~m}(3480 \mathrm{ft})$ was modeled as a $1.7 \mathrm{~m}(5.5 \mathrm{ft})$ fault. The curve response is similar to the curve response we have seen in other horizontal wells when a fault is penetrated. The Upper Terminal Zone Fault Block 5 geological model now includes the $1.7 \mathrm{~m}(5.5 \mathrm{ft})$ fault in this area. 


\section{- Cased Hole Logging}

No cased hole logging took place.

\section{- Recompletions}

Recompletion candidate well Z-61 was perforated across the " $F_{1}$ " and " $F_{0}$ " sands of the Tar Zone in Fault Block V in March, 1997. The perforations were $0.74 \mathrm{~cm}(0.29 ")$ in size and spaced at one (1) per every other foot. Z-61 underwent the steam consolidation process by a portable steam generator during August, 1997.

A total of 16,245 bcwe steam were injected into a total of 18 perforations for sand consolidation. This is a ratio of 902 bcwe steam per perforation. The empirical guideline is 750 bcwe steam per $0.74 \mathrm{~cm}(0.29 ")$ perforation. Z-61 was soaked for a period of 3 weeks and then be placed on production.

Initial production was sand free and metered at $52.1 \mathrm{~m}^{3} / \mathrm{d}(328 \mathrm{~b} / \mathrm{d})$ gross, $16.7 \mathrm{~m}^{3} / \mathrm{d}$ $(105 \mathrm{~b} / \mathrm{d})$ net, for a $68.0 \%$ water cut pumped off on October 8 th, 1997 . The production temperature was $110^{\circ} \mathrm{C}\left(230^{\circ} \mathrm{F}\right)$. Oil production was enhanced by the thermal benefits of steam injection for sand consolidation. The well was last metered on December 2nd, 1997 at $22.7 \mathrm{~m}^{3} / \mathrm{d}(143 \mathrm{~b} / \mathrm{d})$ gross, $4.3 \mathrm{~m}^{3} / \mathrm{d}(27 \mathrm{~b} / \mathrm{d})$ net for an $81.1 \%$ water cut. The production temperature had fallen to $76^{\circ} \mathrm{C}\left(170^{\circ} \mathrm{F}\right)$.

Should this technique prove to be cost effective, other operators could contract out portable steam generators provided they have access to fresh water and fuel. Z-61 is a replacement for the ultra-short radius redrill.

Horizontal redrill candidate $\mathrm{J}-17$ was started in early March. The first attempt to hit the target "Hxo" sand failed as the trajectory coming out of the window was too high and corrections could not be made before exiting the target sand. J-17 was then plugged back and successfully redrilled to the target interval. A significant achievement in drilling this well was turning it $90^{\circ}$ while still in the target sand.

The liner was perforated with $0.74 \mathrm{~cm}(0.29 ")$ holes, $0^{\circ}$ phased, and spaced one (1) 


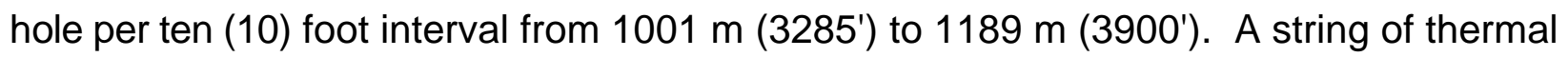
insulated tubing with a thermal packer on bottom were installed. The well is currently on steam injection. Injection rates are much lower than anticipated.

\section{- Technology Transfer}

Researchers presented a paper for the 1997 NIPER Workshop in Midland, TX titled: "Acoustic Logging to Detect Hydrocarbons Through Casing - DOE CLASS 3 Wilmington Waterflood Project".

Researchers attended the 1997 Annual Meeting of the Society of Exploration Geophysicists in Dallas, TX on November 6, 1997.

Researchers presented a paper "Effects of Compaction and Pore Pressure on Velocity and Modulus in Unconsolidated Reservoir Rocks" at a workshop held after the 1997 Annual Meeting of the Society of Exploration Geophysicists in Dallas, TX.

An abstract was submitted to the Society of Professional Well Log Analysts (SPWLA) titled "Determination and Application of Formation Anistropy using a Multiple Frequency, Multiple Spacing Propagation Resistivity Tool from a Horizontal Well, Onshore California" for a presentation that will be given in Keystone, Colorado in May, 1998.

\section{References and Publications}

None 